Costa, João, Maria Lobo \& Fernanda Pratas. 2014. Clitic production by Portuguese and Capeverdean children: omission in bilingualism. PROBUS. ISSN (Online) 1613-4079, ISSN (Print) 0921-4771. DOI: 10.1515/probus-2014-0015

\title{
Clitic production by Portuguese and Capeverdean children: omission in bilingualism ${ }^{1}$
}

João Costa, Maria Lobo and Fernanda Pratas

\begin{abstract}
:
Omission of clitics is often considered a critical marker of language development in children. For this reason, clitic omission in language development has been studied crosslinguistically. Results on clitic production reveal that languages differ with respect to the rates at which clitics are omitted by children, as well as on the duration of the clitic omission stages. This paper compares clitic omission by monolingual and bilingual children acquiring European Portuguese - a language with both clitics and null objects - and Capeverdean Creole - a language with clitics in which null objects are ruled out. We show that omission is only found in monolingual Portuguese, and in bilingual Capeverdean. These results confirm earlier findings on the precocious sensitivity to the availability of null objects, and signal object drop as a critical distinguishing factor for differentiating bilinguals and monolinguals.
\end{abstract}

\section{Introduction.}

A well known fact about language development is that, in languages containing clitics, these can be dropped in children's early productions. Clitic omission has been documented for Catalan (Wexler, Gavarró, \& Torrens, 2004; Gavarró, Torrens, \& Wexler, 2010), European Portuguese (Costa \& Lobo, 2007), French (Jakubowicz et al., 1996; Hamann et al., 1996, Jakubowicz \& Rigaut, 2000), Italian (Schaeffer, 1997), and Spanish (Fujino \& Sano, 2002). For other languages, such as Greek (Tsakali \& Wexler, 2003), Romanian (Babyonyshev \& Marin, 2006), or Serbo-Croatian (Ilic \& Ud Deen, 2004), it has been reported that clitics are omitted only in the early stages and start

\footnotetext{
${ }^{1}$ The research for this paper was supported by the project "Crosslinguistic and Crosspopulation Approaches to Dependencies”, PTDC/MHC-LIN/4812/2012, funded by Fundação para a Ciência e Tecnologia. We thank the project members and two anonymous reviewers for valuable comments.
} 
being produced after age 2 . For some of these languages, there is some controversy regarding the duration of the omission stage.

For European Portuguese, Costa and Lobo (2007) report that omission lasts longer than for Greek, Romanian, and Serbo-Croatian. In fact, Costa and Lobo (2007), Costa, Lobo and Silva (2009), and Silva (2008) report that, at age 6, children still omit clitics. Interestingly, unlike the other languages we have been referring to, adult European Portuguese has null objects freely alternating with pronouns in root contexts, as illustrated in (1): ${ }^{2}$

(1) A: E o teu carro?

and the your car

"What about your car?"

B: $\quad$ Levei $\{\varnothing /-0\}$ para a oficina

took-1sg $\varnothing /$ it to the garage

"I took it to the garage."

The existence of null objects in the adult grammar makes it difficult to know how to analyze a child production in which a verb occurs without a complement: is it a case of clitic omission, as found for other languages, or is it a case of target null object, as found in adult European Portuguese?

Costa and Lobo $(2009,2011)$ argue that clitic omission is an overuse of the null object option on the basis of the following evidence:

a) Children generalize omission to all clitic types, including $1^{\text {st }}$ and $2^{\text {nd }}$ person and reflexive, which differs from languages in which omission is found for $3^{\text {rd }}$ person accusative pronouns only.

b) Yet, the rates of omission are not the same for all clitics. Those clitics that alternate freely with null objects in the adult grammar are omitted at higher rates than those that are obligatorily produced in adult grammar. Specifically,

\footnotetext{
${ }^{2}$ Schwenter (2013) shows that the alternation is partly pragmatically constrained. Crucially, in the contexts used in the experiments, clitics and null objects are in free variation.
} 
reflexive clitics and $1^{\text {st }}$ and $2^{\text {nd }}$ person clitics are omitted less frequently than $3^{\text {rd }}$ person accusative clitics. This shows that children have some sensitivity to the contexts in which a null object legitimately occurs (Costa, Lobo and Silva 2009).

c) Similarly, in contexts in which null objects are ruled out, such as strong islands (Raposo 1986), children omit less clitics than in simple declarative sentences, which, again, reinforces the claim that children are displaying some sensitivity to the contexts in which null objects are legitimate or illegitimate. The island context, for which there is a robust amount of data reported in Costa and Lobo (2009) is particularly revealing, since it is the context differentiating omission from a generalized null object option.

d) The data reported in a)-c) are corroborated by comprehension experiments. Children interpret verbs without a complement transitively in the right pragmatic context. Moreover, they wrongly extend this transitive interpretation in the same contexts in which they overuse null objects. The first fact indicates that they have a null object grammar. The coincidence in overuse in production and comprehension indicates that they overuse the null object option (Costa and Lobo 2009).

The purpose of this paper is to compare monolingual and bilingual children acquiring Portuguese and Capeverdean in order to assess whether there is clitic omission in the latter, and whether the overuse of null objects affects bilingual children. The rationale for the comparison between these two languages is the following: both languages have object clitics (Pratas 2002), but only Portuguese has null objects. We aim at providing answers to the following questions:

A. Is there clitic omission in monolingual Capeverdean creole?

B. Is there crosslinguistic influence in bilingual children?

C. If the answer to B is positive, what is the direction of influence (is there an earlier development of clitics in bilingual Portuguese, or, on the contrary, null objects appear in bilingual Capeverdean?)

The paper is organized in the following way: 
Section 2 provides a description of the pronominal system of Capeverdean and European Portuguese, and discusses the behavior of null objects in the two languages.

In Section 3, we present the results of an elicitation task run with monolingual Portuguese and monolingual Capeverdean children, and with a group of bilingual children acquiring both languages.

In Section 4, we summarize the results, showing that only bilingual participants produce null objects in Capeverdean, and, in Section 5, we discuss them and conclude.

\section{Object pronouns in European Portuguese and Capeverdean.}

Both European Portuguese and Capeverdean have clitic pronouns in object position. As is well known, clitics can be enclitic or proclitic in European Portuguese (Duarte and Matos 2000), but are always enclitic in Capeverdean. This is illustrated for the two languages in the following examples:

(2) European Portuguese:

O João viu $\{-\mathrm{o} /-\mathrm{a} /-\mathrm{os} /-\mathrm{as}\}$.

the João saw him cl $_{\text {l }} /$ her $_{\mathrm{cl}} /$ them $_{\mathrm{cl}-\text { masc }} /$ them $_{\mathrm{cl} \text {-fem }}$

"João saw him/her/them"

(3) Capeverdean:

a. Djon odja-1.

Djon saw $3 \mathrm{sg}_{\mathrm{cl}}$

b. *Djon 1-odja.

Djon saw $3 \mathrm{sg}_{\mathrm{cl}}$ saw

"Djon saw him/her." 
Unlike European Portuguese, Capeverdean does not allow null objects even in the case where a discourse antecedent is retrieved, as shown in (4): ${ }^{3}$

(4) A: Bu fidju?

You son

"What about your son?"

B: $\quad$ Djon odja $\{-1 / * \varnothing\}$.

Djon saw $\operatorname{him}_{\mathrm{cl}} / * \varnothing$

"Djon saw him."

Raposo (1986) argues that null objects in European Portuguese are variables, given the constraints on their distribution. Unlike pronouns, the null object construction is ruled out in strong island contexts, as (7) shows:
A: $\quad$ E o teu filho?
and the your son
"What about your son?"
B: $\quad$ Estou feliz, porque o professor $(\mathrm{o} / * \varnothing)$ elogiou.
am happy because the teacher $\left(\mathrm{him} /{ }^{*} \varnothing\right)$ praised
"I'm happy, because the teacher praised him."

Since this is the same type of context from which movement is ruled out, it is legitimate to claim that the null object is a variable.

\section{Elicitation of pronouns in Capeverdean and European Portuguese.}

Method. In order to elicit pronouns, for the Portuguese monolinguals, we used a task designed for the COST project IS0804. ${ }^{4}$

\footnotetext{
${ }^{3}$ Unlike in Brazilian Portuguese, animacy constraints are not relevant in European Portuguese null objects. Also, it is important to note that clitic placement does not have any relation with null objects. This is confirmed by the fact that null objects are available both in European and in Brazilian Portuguese; but as regards clitic placement, while European Portuguese shows both proclisis and enclisis, only proclisis is available in Brazilian Portuguese.

${ }^{4}$ For information on this project, we refer the reader to www.bi-sli.org
} 
Materials and procedures. The test consists of a sequence of pictures in which a character $\mathrm{X}$ is performing some action on another character $\mathrm{Y}$. The experimenter presents the picture to the child and asks: "What is X doing to Y?". Given the discourse salience of $\mathrm{X}$ and $\mathrm{Y}$, it is expected that they are replaced by pronouns. If a language has null pronouns - both for subject and for object position - the expectation is that the weakest forms are used, or, at least, that a certain degree of optionality emerges between null and overt pronouns.

The task consists of 12 items, plus 5 fillers. The following verbs are used in the task: "pentear" comb, "cortar" cut, "lavar" wash, "secar" dry, "lamber" lick, "desenhar" draw, "molhar" wet, "pintar" paint, "empurrar" push, "puxar” pull, "acordar” wake up, "comer" eat. This list of verbs was selected because they are transitive verbs in all languages being compared with this task (cf. Prévost et al. in press). The fillers included similar pictures with intransitive situations, not targeting a pronominal complement.

In the following picture, we illustrate an example of a test item. When presenting this picture, the experimenter would say: "Look! A boy and a cat. What is the boy doing to the cat?" In a language with pronouns, it is expected that children respond with a pronoun, as in Portuguese: "Está a molhá-lo/ (he) is wetting it." If the language has null objects, the production with a null object is also expected, as in Portuguese "Está a molhar Ø/ (he) is wetting Ø."

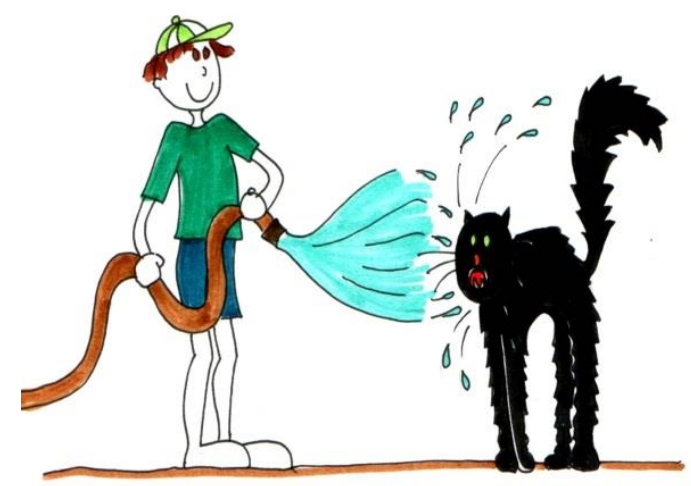

Fig. 1. Example of test item. 
For the Capeverdean monolinguals, we used a task of the same type, but with 20 test items, for which 10 verbs were used twice: "pentia" comb, "puxa" pull, "modja" bite, "laba" wash, "pintxa" push, "brasa" hug, "linpa" clean, "lenbe" lick, "kume" eat. 10 fillers were also used that did not target object pronouns. In this language, the test sentence was of the type: 'Kusé ki mininu sata fazi gatu?' / What is the boy doing to the cat? And the target answer was of the type: 'E sata modja-1 / He is wetting it.' In Capeverdean there are no attested null objects, hence the answer 'E sata modja $\varnothing$ / he is wetting $\varnothing^{\prime}$ is ungrammatical.

For the bilingual group, since they were to be tested also in Portuguese, we added an extra condition, in which the pronoun is elicited within an island. This test, designed for the project COST A33 (cf. Varlokosta et al. in press), takes into account Costa and Lobo's (2007) idea that, in order to control for null objects, the elicitation must be done in a context in which the target grammar rules out this option. It has now been introduced in the current experiment: 10 items of this island condition have been used instead of fillers. Like the one described above, this condition consisted of a picture presented to the child and a question that triggered a reply with a because-clause containing a pronominal. The context strongly favors the use of a pronominal by making the antecedent very salient in the discourse. First, a picture was presented in which one animate character was performing an action on another character or object. The experimenter described the picture in a sentence and then asked the child a whyquestion. The verbs used were: kick, cover, comb, wake up, paint, tie, wash, eat, catch, wet.

We will refer to this condition as the Island Test, and to the first one as the Simple Sentence Test. The island test was only run on the bilinguals, since islands are irrelevant in Capeverdean, and have proven not to be distinguished from root contexts in monolingual children acquiring Portuguese in Costa and Lobo (2009).

Participants. The Simple Sentence Test was run in Portuguese to a group of 20 typically developing monolingual children acquiring European Portuguese, with age between 5;0 and 5;11 (mean: 5;5; SD: 3.2), 10 male and 10 female. The same version of the test was applied to 20 adults, who acted as the control group. The test was applied to 
children in a daycare center in the area of Lisbon, and to adults at Universidade Nova de Lisboa.

The Capeverdean version of the test was run in Cape Verde on 24 children with age between 4;0 and 5;11. 12 of these children had ages between 4 and 4;11 (mean 4;4. SD: 2.1), 2 male and 10 female, and the other 12 had ages between 5;0 and 5;11 (mean: 5;4. SD: 3.2), 5 male, 7 female. In addition, the test was run on 10 monolingual adults speakers of Capeverdean (tested in Cape Verde), with an average age of 31. These children were tested at 'Pimpão' and 'Disneylândia' kindergarten in Praia, Santiago Island, the same city where the adults were tested.

The bilingual group consisted of a group of 9 typically developing children with ages between 5;1 and 6;0 (mean: 5;4. SD: 3.0). These children were born in Portugal, and are sequential bilingual, who first learned Capeverdean, and started having contact with Portuguese when they went to daycare, at the age of 2 . This group was tested on both versions of the Simple Sentence Test and the Island Test, that is, in Portuguese and Capeverdean. Two different experimenters - native speakers of the relevant language run the tests on different days. The Capeverdean version was run first, since this is the language in which pronouns are obligatory, and no variation is expected. A group of 8 bilingual adults (mean age: $38 ; 7$ ) was also tested in the two versions of the two tasks. The bilingual groups were tested at Cova da Moura neighborhood in the Lisbon area.

In all instances of the tasks, the subjects were tested individually, and their responses were recorded in a digital audio recorder, and transcribed by two experimenters during and after the test. No time limit was imposed, and no stimulus or correction was given depending on the type of response, besides general encouragement to pursue the task and a final reward after completion of the task (for the children only).

Scoring. The responses were coded according to the following categories:

Clitic: whenever a clitic was used. For the purpose of this paper, it was not taken into consideration whether the participants were target-like in selecting the appropriate case, number or gender for the clitic. ${ }^{5}$

Null: when no lexical form was used.

$D P:$ when the participant repeated the DP used in the prompt.

\footnotetext{
${ }^{5}$ As shown in Silva (2008), there are very few clitic errors in the data. The percentages of non-target clitic selection are residual.
} 
Strong: when the participant used a strong pronoun instead of a clitic.

Other: whenever there was no response, or some other type of response occurred (e.g. use of an intransitive verb)

\section{Results.}

We present the results of the tests by group of participants.

\subsection{Monolingual Portuguese.}

The results of the Simple Sentence Test, run to monolingual children acquiring European Portuguese, and to a group of adult speakers, reproduced earlier findings reported in Costa, Lobo and Silva (2009). Both children and adults omit clitics, because the null object is a legitimate option in the target grammar. Since this test uses accusative clitics only, and no island context is used, the higher rate of omission in children may be explained if indeed there is an overuse of the null object option.

The following tables present the results for the two groups:

Table 1. Children results - Monolingual European Portuguese - Simple Sentence Test

\begin{tabular}{|l|l|l|}
\hline Clitics & $58 / 240$ & $19,3 \%$ \\
\hline DP & $25 / 240$ & $8,3 \%$ \\
\hline Null & $148 / 240$ & $49,3 \%$ \\
\hline Strong pronouns & $2 / 240$ & $1 \%$ \\
\hline Other/No response & $6 / 240$ & $2 \%$ \\
\hline
\end{tabular}

Table 2. Adult results - Monolingual European Portuguese - Simple Sentence Test

\begin{tabular}{|l|l|l|}
\hline Clitics & $135 / 240$ & $56 \%$ \\
\hline DP & $45 / 240$ & $19 \%$ \\
\hline Null & $60 / 240$ & $25 \%$ \\
\hline
\end{tabular}

It is interesting to observe that children produce less clitics than adults, which shows that they have not yet reached an adult stage, as argued in Costa, Lobo and Silva (2009), but, at the same time, children master the pragmatics of the context, and behave adult- 
like in selecting null objects as a valid option. The rate of DPs is more surprising, since the high accessibility of the antecedent should prompt the use of a weak form (pronominal or null). The replacement of clitics by DPs is attested in the literature for children (Schaeffer 1997, Wexler, Gavarró and Torrens 2004).

Let us then consider the individual data of children and adults:

Table 3. Simple Sentence Test - Individual data-Monolingual Portuguese children

\begin{tabular}{|l|l|l|l|l|l|}
\hline \multicolumn{1}{|c|}{ Participant } & \multicolumn{1}{|c|}{ Clitic } & \multicolumn{1}{|c|}{ DP } & \multicolumn{1}{|c|}{ Null } & Strong & $\begin{array}{l}\text { Other/No } \\
\text { response }\end{array}$ \\
\hline 1 & 66,6 & 8,33 & 16,66 & 0 & 8,33 \\
\hline 2 & 33,3 & 16,6 & 50 & 0 & 0 \\
\hline 3 & 0 & 0 & 91,66 & 0 & 8,33 \\
\hline 4 & 16,6 & 25 & 50 & 8,33 & 0 \\
\hline 5 & 0 & 0 & 100 & 0 & 0 \\
\hline 6 & 75 & 0 & 16,66 & 0 & 8,33 \\
\hline 7 & 8,33 & 41,6 & 33,33 & 0 & 16,6 \\
\hline 8 & 0 & 8,33 & 91,66 & 0 & 0 \\
\hline 9 & 66,6 & 8,33 & 25 & 0 & 0 \\
\hline 10 & 41,6 & 8,33 & 50 & 0 & 0 \\
\hline 11 & 16,6 & 41,6 & 41,66 & 0 & 0 \\
\hline 12 & 16,6 & 8,33 & 58,33 & 8,33 & 8,33 \\
\hline 13 & 0 & 0 & 100 & 0 & 0 \\
\hline 14 & 16,6 & 8,33 & 75 & 0 & 0 \\
\hline 15 & 41,6 & 16,6 & 33,33 & 8,33 & 0 \\
\hline 16 & 0 & 0 & 100 & 0 & 0 \\
\hline 17 & 0 & 16,6 & 83,33 & 0 & 0 \\
\hline & & & & 0 & 0 \\
\hline & 0 & 0 & & 0 & 0 \\
\hline
\end{tabular}




\begin{tabular}{|l|l|l|l|l|l|}
\hline 18 & 0 & 0 & 100 & 0 & 0 \\
\hline 19 & 41,6 & 0 & 58,33 & 0 & 0 \\
\hline 20 & 41,6 & 0 & 58,33 & 0 & 0 \\
\hline
\end{tabular}

As shown in table 3, there was obvious inter- and intra-speaker variability, which turns out to be irrelevant, since different strategies were adopted by different children. But almost all had a preference for omission, confirming the tendency to omit the complement. This can be compared with the individual adult performance:

Table 4. Simple Sentence Test - Individual data - Monolingual Portuguese adults

\begin{tabular}{|l|l|l|l|}
\hline \multirow{2}{*}{ Participant } & \multicolumn{1}{|c|}{ Clitic } & \multicolumn{1}{|c|}{ DP } & \multicolumn{1}{c|}{ Null } \\
\hline 1 & 41,66 & 8,33 & 50 \\
\hline 2 & 66,66 & 0 & 33,33 \\
\hline 3 & 66,66 & 8,33 & 25 \\
\hline 4 & 50 & 16,66 & 33,33 \\
\hline 5 & 66,66 & 0 & 33,33 \\
\hline 6 & 83,33 & 0 & 16,66 \\
\hline 7 & 0 & 0 & 100 \\
\hline 8 & 100 & 0 & 0 \\
\hline 9 & 100 & 0 & 0 \\
\hline 10 & 0 & 0 & 100 \\
\hline 11 & 100 & 0 & 0 \\
\hline 12 & 0 & 100 & 0 \\
\hline 13 & 0 & 0 & 100 \\
\hline 14 & 91,66 & 8,33 & 0 \\
\hline 15 & 83,33 & 0 & 16,66 \\
\hline 16 & 0 & 91,66 & 8,33 \\
\hline 17 & 91,66 & 0 & 8,33 \\
\hline & & & \\
\hline 5 & 0 & 0 \\
\hline
\end{tabular}




\begin{tabular}{|l|l|l|l|}
\hline 18 & 100 & 0 & 0 \\
\hline 19 & 100 & 0 & 0 \\
\hline 20 & 33,33 & 66,66 & 0 \\
\hline
\end{tabular}

Again, like in the children group, we observe some preferences and tendencies, and some intra-speaker variation. Crucially, clitics and null objects freely alternate for some adults. Also, when individual data are considered, it becomes obvious that the rate of DP responses is basically coming from two participants, so it cannot be taken as an expressive result for the relevant age group.

\subsection{Monolingual Capeverdean.}

Let us now consider the results for monolingual Capeverdean children and adults, tested in the Capeverdean version of the Simple Sentence Test. As shown in the following tables, both children and adults produced clitics almost at ceiling. The omission rates were insignificant.

Table 5. Simple Sentence Test-Monolingual Capeverdean Children - 4 year olds

\begin{tabular}{|l|l|l|}
\hline Clitic & $219 / 240$ & $91,25 \%$ \\
\hline DP & $13 / 240$ & $5,42 \%$ \\
\hline Null & $8 / 240$ & $3,33 \%$ \\
\hline $\begin{array}{l}\text { Other/No } \\
\text { response }\end{array}$ & 0 & $0 \%$ \\
\hline
\end{tabular}

Table 6. Simple Sentence Test-Monolingual Capeverdean Children - 5 year olds

\begin{tabular}{|l|l|l|}
\hline Clitic & $224 / 240$ & $93,33 \%$ \\
\hline DP & $8 / 240$ & $3,33 \%$ \\
\hline Null & $8 / 240$ & $3,33 \%$ \\
\hline $\begin{array}{l}\text { Other/No } \\
\text { response }\end{array}$ & 0 & $0 \%$ \\
\hline
\end{tabular}


Table 7. Simple Sentence Test-Monolingual Capeverdean Adults

\begin{tabular}{|l|l|l|}
\hline Clitic & $185 / 200$ & $92,5 \%$ \\
\hline DP & $5 / 200$ & $2,5 \%$ \\
\hline Null & $10 / 200$ & $5 \%$ \\
\hline $\begin{array}{l}\text { Other/No } \\
\text { response }\end{array}$ & 0 & $\%$ \\
\hline
\end{tabular}

As shown above, the three age groups perform alike, and clitics are massively produced at all ages, even by the younger group. No differences are found between children and adults. Given the strong consistency of this performance, and the obvious preference for clitics, we think the presentation of individual results is irrelevant.

\subsection{Bilingual Capeverdean-Portuguese}

Let us now observe the results for bilingual children acquiring European Portuguese and Capeverdean and for the bilingual adult control group.

First, we present the data for the Portuguese version of the Simple Sentence Test. As shown in the following tables, both children and adults had some degree of omission in this test:

Table 8. Simple sentence test-Bilingual children-Portuguese version

\begin{tabular}{|l|l|l|}
\hline Clitic & $41 / 180$ & $22,78 \%$ \\
\hline DP & $17 / 180$ & $9,44 \%$ \\
\hline Null & $99 / 180$ & $55 \%$ \\
\hline Strong pronouns & $6 / 180$ & $3,33 \%$ \\
\hline Other/No response & $17 / 180$ & $9,44 \%$ \\
\hline
\end{tabular}

Table 9. Simple sentence test-Bilingual adults - Portuguese version 


\begin{tabular}{|l|l|l|}
\hline Clitic & $85 / 160$ & $53,13 \%$ \\
\hline DP & $54 / 160$ & $33,75 \%$ \\
\hline Null & $18 / 160$ & $11,25 \%$ \\
\hline Other/No response & $3 / 160$ & $1,88 \%$ \\
\hline
\end{tabular}

Like monolingual Portuguese children, bilingual children, when tested in Portuguese, produce sentences with a null object. The same holds for adults, although the rate of omission decreases, and the number of clitics increases. This is not different from what was found for monolingual speakers. Interestingly, the two groups behave alike even in the fact that there is DP use by some speakers.

Let us then consider the individual data of children and adults:

Table 10. Simple sentence test - Bilingual children - Portuguese version

\begin{tabular}{|l|l|l|l|l|l|}
\hline Participant & \multicolumn{1}{|c|}{ Clitic } & \multicolumn{1}{|c|}{ DP } & Null & Strong & $\begin{array}{l}\text { Other/No } \\
\text { response }\end{array}$ \\
\hline 1 & 5 & 15 & 50 & 0 & 30 \\
\hline 2 & 5 & 50 & 25 & 0 & 20 \\
\hline 3 & 45 & 5 & 40 & 5 & 5 \\
\hline 4 & 90 & 0 & 10 & 0 & 0 \\
\hline 5 & 25 & 0 & 40 & 20 & 15 \\
\hline 6 & 5 & 0 & 90 & 5 & 0 \\
\hline 7 & 20 & 5 & 60 & 0 & 15 \\
\hline 8 & 0 & 10 & 90 & 0 & 0 \\
\hline 9 & 10 & 0 & 90 & 0 & 0 \\
\hline
\end{tabular}

Table 11. Simple sentence test - Bilingual adults - Portuguese version

\begin{tabular}{|l|l|l|l|}
\hline Participant & Clitic & DP & Null \\
\hline 1 & 20 & 60 & 15 \\
\hline
\end{tabular}




\begin{tabular}{|l|l|l|l|}
\hline 2 & 85 & 15 & 0 \\
\hline 3 & 15 & 85 & 0 \\
\hline 4 & 45 & 10 & 40 \\
\hline 5 & 100 & 0 & 0 \\
\hline 6 & 50 & 50 & 0 \\
\hline 7 & 30 & 30 & 30 \\
\hline 8 & 80 & 20 & 0 \\
\hline
\end{tabular}

Recall that the island version of the test aimed at creating a context in which null objects are ruled out (Costa and Lobo 2007), and observe how this group performed in the Portuguese version of the Island Test.

Table 12. Island test-Bilingual children-Portuguese version

\begin{tabular}{|l|l|l|}
\hline Clitic & $22 / 90$ & $24,44 \%$ \\
\hline DP & $9 / 90$ & $10 \%$ \\
\hline Null & $40 / 90$ & $44,45 \%$ \\
\hline Strong pronouns & $12 / 90$ & $13,33 \%$ \\
\hline Other/No response & $7 / 90$ & $7,78 \%$ \\
\hline
\end{tabular}

Table 13. Island test-Bilingual adults - Portuguese version

\begin{tabular}{|l|l|l|}
\hline Clitic & $56 / 80$ & $70 \%$ \\
\hline DP & $24 / 80$ & $30 \%$ \\
\hline Null & 0 & $0 \%$ \\
\hline Other/No response & 0 & $0 \%$ \\
\hline
\end{tabular}

Again, both groups behaved as described in the literature: adults appear to know that null objects are ruled out in islands, whereas children overused null objects in the island context. The behavior of adults contrasts with the behavior of children, and they crucially treat island contexts differently from root sentences, in that only adults ban null objects from the former. This result is ambiguous, since it might indicate that the 
children are overusing the null object, but do not know the restriction banning them from islands or that the omitted element is not an adult-like null object. Similar results were obtained when we tested $1^{\text {st }}$ and $2^{\text {nd }}$ person contexts (Costa, Lobo and Silva 2012). The results on comprehension by Costa and Lobo $(2009$, 2011) confirm that this is an overuse of the null object, since children behave in this condition in the same way they do in other overuse contexts, like reflexive contexts. Also, in Silva (2008), it is shown that the overuse of null objects decreases at different ages in different contexts, which indicates that this is not just a generalized complement omission. By hypothesis, bilingual children are performing like monolingual children.

Let us now check how bilingual children and adults performed in the Capeverdean versions of the same tests. First, consider the Simple Sentence Test:

Table 14. Simple sentence test - Bilingual children-Capeverdean version

\begin{tabular}{|l|l|l|}
\hline Clitic & $50 / 180$ & $27,78 \%$ \\
\hline DP & $27 / 180$ & $15 \%$ \\
\hline Strong pronouns & $2 / 180$ & $1,11 \%$ \\
\hline Null & $93 / 180$ & $51,66 \%$ \\
\hline Other/No response & $8 / 180$ & $4,45 \%$ \\
\hline
\end{tabular}

Table 15. Simple sentence test - Bilingual adults - Capeverdean version

\begin{tabular}{|l|l|l|}
\hline Clitic & $132 / 160$ & $82,5 \%$ \\
\hline DP & $21 / 160$ & $13,12 \%$ \\
\hline Null & 0 & $0 \%$ \\
\hline Other/No response & $7 / 160$ & $4,38 \%$ \\
\hline
\end{tabular}

Unlike what happened for monolingual Capeverdean children, here children and adults performed differently, in that children produced target-deviant sentences with null objects. Adults consistently rejected null objects. The same happened in the Island Test, as shown in Tables 14 and 15: 
Table 16. Island test - Bilingual children - Capeverdean version

\begin{tabular}{|l|l|l|}
\hline Clitic & $37 / 90$ & $41,11 \%$ \\
\hline DP & $16 / 90$ & $17,77 \%$ \\
\hline Null & $27 / 90$ & $30 \%$ \\
\hline Strong pronouns & $4 / 90$ & $4,45 \%$ \\
\hline Other/No response & $6 / 90$ & $6,66 \%$ \\
\hline
\end{tabular}

Table 17. Island test - Bilingual adults - Capeverdean version

\begin{tabular}{|l|l|l|}
\hline Clitic & $72 / 80$ & $90 \%$ \\
\hline DP & $2 / 80$ & $2,5 \%$ \\
\hline Null & 0 & $0 \%$ \\
\hline Other/No response & $6 / 80$ & $7,5 \%$ \\
\hline
\end{tabular}

Again, adults clearly know that null objects are ruled out in the island context - and that Capeverdean rules out null objects, but children use null objects within the island, as they did in the Portuguese version. Although we do not have comprehension tests for the bilingual children, we hypothesize that, like in Portuguese, they are overusing the null object, extending it to a context in which it is not legitimate.

\subsection{Summary of results.}

After a one way ANOVA analysis of the results, we observed that there was no significant difference between children and adults in the production of DPs, but there were significant differences in clitic $(\mathrm{f}=10,740, \mathrm{p}=0,002)$ and null object production $(\mathrm{F}=12,054, \mathrm{p}=0,001)$. This confirms previous findings by Costa, Lobo and Silva, and shows that the rates of clitic production by children are not like their adult target. This is summarized in the following table:

Table 18: 
ANOVA

\begin{tabular}{|ll|r|r|r|r|r|}
\hline & & \multicolumn{1}{c|}{$\begin{array}{c}\text { Sum of } \\
\text { Squares }\end{array}$} & df & Mean Square & \multicolumn{1}{c|}{ F } & Sig. \\
\hline DP & Between Groups & 211,278 & 1 & 211,278 &, 365 &, 549 \\
& Within Groups & 21988,887 & 38 & 578,655 & & \\
& Total & 22200,165 & 39 & & & \\
\hline Nulo & Between Groups & 12542,576 & 1 & 12542,576 & 12,054 &, 001 \\
& Within Groups & 39539,514 & 38 & 1040,514 & & \\
& Total & 52082,091 & 39 & & & \\
\hline clitics & Between Groups & 11982,675 & 1 & 11982,675 & 10,740 & \\
& Within Groups & 42394,918 & 38 & 1115,656 & & \\
& Total & 54377,593 & 39 & & & \\
\hline
\end{tabular}

The same statistical analysis confirms that there are no significant differences between monolingual and bilingual children tested in European Portuguese:

Table 19:

ANOVA

\begin{tabular}{|ll|r|r|r|r|r|}
\hline & \multicolumn{1}{c|}{$\begin{array}{c}\text { Sum of } \\
\text { Squares }\end{array}$} & df & Mean Square & \multicolumn{1}{c|}{ F } & Sig. \\
\hline DP & Between Groups & 5,656 & 1 & 5,656 &, 029 &, 866 \\
& Within Groups & 5238,572 & 27 & 194,021 & & \\
& Total & 5244,227 & 28 & & &, 576 \\
\hline Nulo & Between Groups & 275,641 & 1 & 275,641 &, 320 & \\
& Within Groups & 23267,633 & 27 & 861,764 & &, 899 \\
& Total & 23543,275 & 28 & &, 016 & \\
\hline clitics & Between Groups & 11,375 & 1 & 11,375 & & \\
& Within Groups & 18707,849 & 27 & 692,883 & & \\
& Total & 18719,223 & 28 & & & \\
\hline
\end{tabular}

This contrasts with the findings for monolingual and bilingual Capeverdean children. As shown in the next table, there are significant differences between these two groups in all types of results: production of DPs $(\mathrm{F}=6,424, \mathrm{p}=0,017)$, production of clitics $(\mathrm{F}=104,203, \mathrm{p}=<0,001)$ and production of null objects $(\mathrm{F}=77,054, \mathrm{p}=<0,001)$. 
ANOVA

\begin{tabular}{|ll|r|r|r|r|r|}
\hline & & \multicolumn{1}{c|}{$\begin{array}{c}\text { Sum of } \\
\text { Squares }\end{array}$} & df & Mean Square & F & Sig. \\
\hline DP & Between Groups & 738,920 & 1 & 738,920 & 6,424 &, 017 \\
& Within Groups & 3565,625 & 31 & 115,020 & & \\
& Total & 4304,545 & 32 & & &, 000 \\
\hline Nulo & Between Groups & 15290,909 & 1 & 15290,909 & 77,286 & \\
& Within Groups & 6133,333 & 31 & 197,849 & &, 000 \\
& Total & 21424,242 & 32 & & & \\
\hline clitics & Between Groups & 27242,456 & 1 & 27242,456 & 104,203 & \\
& Within Groups & 8104,514 & 31 & 261,436 & & \\
& Total & 35346,970 & 32 & & & \\
\hline
\end{tabular}

Based on the descriptive results and on the statistical analyses, we summarize the most interesting difference found across groups:

Monolingual Portuguese children vs. Monolingual Portuguese adults: we observed that monolingual Portuguese children know that null objects are allowed, but the literature reports that they overuse them in island contexts. Monolingual adults use more clitics, but they also use null objects. The literature reports that they ban null objects in island contexts.

Monolingual Portuguese children vs. Monolingual Capeverdean children: the results show that only the Portuguese children use null objects in root contexts. Monolingual Capeverdean children use clitics in simple sentences and basically do not produce sentences with null objects.

Monolingual Portuguese adults vs. Monolingual Capeverdean adults: only Portuguesespeaking adults use some null objects in root contexts. Capeverdean adults use clitics all the time.

Monolingual Portuguese children vs. Bilingual children (tested in Portuguese): these two groups performed similarly. Both groups use null objects productively in root contexts. The bilingual group performed as reported in the literature for monolinguals, overusing null objects in island contexts. 
Monolingual Capeverdean children vs. Bilingual children (tested in Capeverdean): these two groups behaved differently. Unlike monolingual children, bilinguals used null objects in Capeverdean.

Monolingual Portuguese adults vs. Bilingual adults (tested in Portuguese): the two control groups behaved alike, in reckoning that null objects are allowed in root sentences, but ruled out in islands.

Monolingual Capeverdean adults vs. Bilingual adults (tested in Capeverdean): both groups performed similarly, since they both ruled out the null object option, and massively produced clitics.

In short, one can state the following generalizations:

a) Monolingual children know the properties of their grammars with respect to the availability of clitics and null objects, although there is an overuse of null objects by Portuguese children;

b) Bilingual adults differentiate the two languages they speak with respect to the availability of clitics and null objects;

c) Bilingual children display interference only in one direction: the availability of null objects in Portuguese affects the production in Capeverdean. Another interesting fact about Capeverdean children is that the rate of "other responses" increases 4 times the figure shown by Portuguese monolingual children, as noted by a reviewer. This may be an effect of children's inability to decide, due to interference.

\section{Discussion.}

The results presented in the previous section confirm previous findings showing that children, at age 5, are able to produce clitics crosslinguistically (Varlokosta et al. in preparation). To our knowledge, this had not been reported for Capeverdean, and it is interesting to confirm that this language is not different from other languages in this domain. Further, it is interesting to observe that, at the ages tested, Capeverdean monolinguals do not omit clitics. 
The data further confirm the hypothesis put forward in Costa and Lobo (2009) that Portuguese monolingual children know the null object status of their language, but still overuse null objects at age 5. The results on comprehension reported in Costa and Lobo (2009) for Portuguese strongly argue for the hypothesis on the overuse of null objects, since children interpret transitively verbs without a complement, which argues for a null object grammar. Unlike a reviewer suggests, omission is not a side-effect of some kind of difficulty posed by variable clitic placement in Portuguese, since children display difficulties with placement at an age in which omission ceased, as shown in Costa, Fiéis and Lobo (2013).

The novel finding of this study is the direction of the crosslinguistic influence in bilingualism. Bilingual children in our study (who happen to start acquiring Portuguese only when they go do daycare centers, at the age of 2) overuse null objects in Capeverdean, rather than extend the massive use of clitics from Capeverdean to Portuguese. This is an interesting fact, in which one detects a one-way interaction between languages: the null form takes over the lexical form, not the opposite.

In what follows, we explain this one-way interference resorting to Muller and Hulk's (2001) interface hypothesis on crosslinguistic influences in bilingualism.

According to Muller and Hulk (2001), crosslinguistic interference is expected in areas of interface. The acquisition of null objects in Portuguese is a clear area of interface between syntax and discourse. Children have to figure out in which contexts a null object does not freely alternate with a clitic, in order to rule out the null object option in a restricted set of contexts.

However, what we have to explain is why the crosslinguistic interference only operates in one way - that is, why there are more null objects than clitics in Capeverdean, and not more clitics than null objects in Portuguese. This actually follows from Rizzi's (2005) proposal, combined with Muller and Hulk (2001).

Rizzi (2005) proposes that performance tasks are guided by a simplification principle, stating that the learner should adopt parametric values reducing computational load on the production system, if these parametric values are not contradicted by positive evidence. This is particularly relevant for cases of ellipsis. According to Rizzi (2005), 'it looks plausible that any grammatically licit ellipsis will reduce the burden of the 
production system, by allowing it not to pronounce chunks of the linguistic representation'. This is why there is a contrast between the acquisition of parameters that involve grammatically licit ellipsis and the acquisition of those that do not: delays are known to occur in the acquisition of root subject drop, determiner drop or copula omission, given the availability of null forms; syntactic phenomena like directionality or V-to-I, on the contrary, are acquired earlier. The point is that directionality and V-Movement may be largely irrelevant in increasing or decreasing the burden of the production system.

As mentioned above, the choice for null objects is one in which there are interface effects. As such, there is crosslinguistic interference in bilingualism. If this is the case, children have supporting evidence to adopt a positive parameter value for null objects even in Capeverdean, because of the availability of null objects in Portuguese. In other words, the Portuguese input, via interference, provides the evidence for children to maintain the value that alleviates the production system, that is, the null form. The influence does not occur in the other direction, since an option for a lexical form instead of a null form is not supported by the need to alleviate the task of production.

In Costa and Lobo (2011), it is argued that variability in the input induces a delay in the acquisition of clitics and null objects by monolingual children. For bilingual children, we contend that the same type of input variability induces crosslinguistic interference and a consequent one-way delay.

As a final note, it is interesting to observe that, through the tests discussed above, we identified a crucial marker to differentiate monolingual development from bilingual development in the acquisition of European Portuguese and Capeverdean.

\section{References.}

Babyonyshev, M. \& Marin, S. 2006. Acquisition of Romanian pronominal clitics. In A. Gavarró \& C. Lleó (Eds.). Catalan Journal of Linguistics, 5. The Acquisition of Romance, 17-44.

Costa, J. \& Lobo, M. 2007. Clitic omission, null objects or both in the acquisition of European Portuguese. In S. Baauw, F. Drijkonongen \& M. Pinto (Eds.), Romance Languages and Linguistic Theory 2005. Amsterdam: John Benjamins, 59-72.

Costa, J. \& Lobo, M. 2009. Clitic omission in the acquisition of European Portuguese: Data from comprehension. In A. Pires \& J. Rothman (Eds.), Minimalist Inquiries into Child Language Acquisition. Case Studies across Portuguese, Berlin/New York: Mouton de Gruyter, 63-84. 
Costa, J., M. Lobo \& C. Silva (2009). Null objects and early pragmatics in the acquisition of European Portuguese. In Probus 21, pp. 143-162.

Costa, J., M. Lobo \& C. Silva (2012). Which category replaces an omitted clitic? The case of European Portuguese. In Pedro Guijarro-Fuentes \& Maria Pilar Larrañaga, eds. Pronouns and clitics in early acquisition. Berlin/New York: Mouton DeGruyter; 105-130.

Costa, J. \& M. Lobo. (2011). Objeto nulo na aquisição do português europeu: pro ou variável? XXVI Encontro Nacional da Associação Portuguesa de Linguística. Textos Seleccionados 2010; 197-207.

Costa, J., A. Fiéis and M. Lobo (2013) Input variability and late acquisition: clitic misplacement in European Portuguese. To appear in Lingua

Costa, J., F. Pratas \& A. Barragon (2012). Null subjects in Monolingual and Bilingual, Typical and Atypical Development. (submitted for publication)

Fujino, H. \& Sano, T. 2002. Aspects of the null object phenomenon in child Spanish. In A.T. Pérez-Leroux \& J. Muñoz Liceras (Eds.), The Acquisition of Spanish Morphosyntax. Dordrecht: Kluwer, 67-88.

Gavarró, A., Torrens, V. \& Wexler, K. 2010. Object clitic omission: Two language types. Language Acquisition, 17 (4), 192-219.

Hamann, C., Rizzi, L. \& Frauenfelder, U. 1996. On the acquisition of the pronominal system in French. In H. Clahsen (Ed.), Generative Perspectives on Language Acquisition. Amsterdam: John Benjamins, 309-334.

Ilic, T. \& Ud Deen, K. 2004. Object raising and cliticization in Serbo-Croatian child language. Proceedings of GALA 2003, Volume 1, LOT, 235-243.

Jakubowicz, C., Müller, N., Kang, O.-K., Riemer, B. \& Rigaut, C. 1996. On the acquisition of the pronominal system in French and German, In Proceedings of the 20th annual Boston University Conference on Language Development. Somerville MA: Cascadilla Press, 374-385.

Jakubowicz, C. \& Rigaut, C. 2000. L'acquisition des clitiques nominatifs et des clitiques objets en Français [The acquisition of nominative and object clitics in French]. The Canadian Journal of Linguistics, 45, 119-158.

Müller, N. \& Hulk, A. (2001). Crosslinguistic influence in bilingual language acquisition: Italian and French as recipient languages. Bilingualism: Language and Cognition 4 (1), 1-21.

Pratas, F. (2002). O sistema pronominal no caboverdiano. Lisbon: Colibri 
Raposo, E. 1986. On the null object construction in European Portuguese. In O. Jaeggli \& C. Silva-Corvalán (Eds.), Studies in Romance Linguistics. Dordrecht: Foris, 373390.

Reinhart, T. \& E. Reuland (1993). Reflexivity. In Linguistic Inquiry 24 (1993), p. 657720

Rizzi, L. (2005). Grammatically-based target-inconsistencies in child language. Ms., University of Sienna.

Schaeffer, J. 1997. Direct Object Scrambling in Dutch and Italian Child Language. UCLA Dissertations in Linguistics, Number 17.

Schaeffer, J. 2000. The Acquisition of Direct Object Scrambling and Clitic Placement. Amsterdam/Philadelphia: John Benjamins.

Schwenter, Scott. 2013. Differential object marking... in Portuguese? Paper presented at Portuguese Linguistics in the United States. University of Georgia at Athens, November 2013

Silva, C. 2008. Assimetrias na aquisição de clíticos diferenciados em português europeu. MA thesis, Universidade Nova de Lisboa.

Tsakali, V. \& Wexler, K. 2004. Why children omit clitics in some languages, but not in others: New evidence from Greek. Proceedings of GALA, 2, LOT, 493-504

Varlokosta et al. (in preparation). Elicitation of Clitics and Strong Pronouns in 16 languages.

Wexler, K., Gavarró, A. \& Torrens, V. 2004. Feature checking and object clitic omission in child Catalan and Spanish. In R. Bok-Bennema, B. Hollebrandse, B. Kampers-Manhe \& P. Sleeman (Eds.), Romance Languages and Linguistic Theory 2002, John Benjamins, Amsterdam, 253-70. 